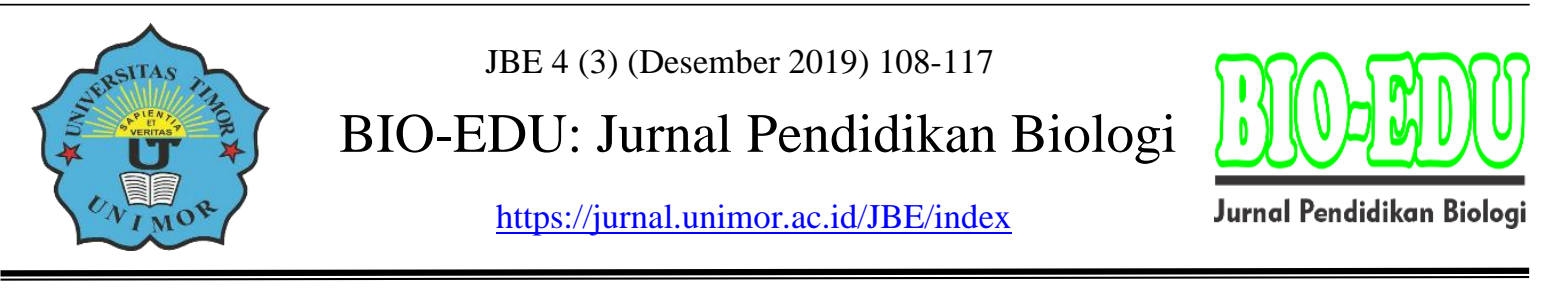

\title{
Efek Pemberian Ekstrak Etanol Daun Leilem (Clerodendrum minahasae) terhadap Kadar Kreatinin, Asam Urat dan Ureum pada Tikus Putih (Rattus novergicus)
}

\author{
Rolef Rumondor ${ }^{1}$, Muh. Rino Komalig ${ }^{2}$, Kamaluddin ${ }^{3}$ \\ ${ }^{1}$ Program Studi Farmasi, Universitas Trinita \\ 2 Program Studi Kesehatan Keselamatan Kerja, Universitas Trinita \\ ${ }^{3}$ Program Studi Pendidikan Biologi, Universitas Timor \\ Email: rolefrumondor@gmail.com
}

DOI: https://doi.org/10.32938/jbe.v4i3.419

\begin{abstract}
Abstrak
Kemajuan ilmu pengetahuan di bidang pengobatan sekarang ini sangat pesat seiring dengan kemajuan teknologi, namun penggunaan obat-obatan tradisional semakin digemari. Hal ini disebabkan rendahnya efek samping yang ditimbulkan oleh obat-obatan tradisional, praktis pemakaiannya, mudah memperolehnya dan harga yang terjangkau. Sulawesi Utara merupakan salah satu daerah yang memiliki begitu banyak jenis tumbuhan, diantaranya tumbuhan leilem (Clerodendrum minahassae) dari genus Clerodendrum. Tumbuhan leilem merupakan tumbuhan endemik Sulawesi Utara yang oleh masyarakat Minahasa sering dikonsumsi sebagai sayur dan biasanya ditambahkan pada pengolahan daging. Penelitian ini bertujuan untuk mengetahui pengaruh ekstrak etanol daun leilem terhadap gambaran nilai ureum, asam urat dan kreatinin pada tikus putih yang diinduksi etlen glikol. Rancangan penelitian, kelompok perlakuan dibagi menjadi 5 kelompok. Kelompok kontrol (P0), Kelompok etilen glikol (P1), Kelompok perlakuan batugin (P2), kelompok ekstrak etanol daun leilem dosis $150 \mathrm{mg} / \mathrm{kgBB}$ (P3), dan kelompok ekstrak etanol daun leilem dosis $300 \mathrm{mg} / \mathrm{kgBB}$ (P4). Hasil penelitian menunjukkan bahwa ekstrak etanol daun leilem $150 \mathrm{mg} / \mathrm{kgBB}$ dan $300 \mathrm{mg} / \mathrm{kgBB}$ dapat menurunkan kadar ureum, kreatinin dan asam urat pada tikus dengan perlakuan etilen glikol. Ekstrak etanol daun leilem 150 $\mathrm{mg} / \mathrm{kgBB}$ lebih baik dalam menurunkan kadar ureum, kreatinin dan asam urat tikus dibandingkan dengan dosis $300 \mathrm{mg} / \mathrm{kgBB}(\mathrm{p}<0.05)$.
\end{abstract}

Kata kunci : Leilem, ureum, kreatinin, asam urat

\begin{abstract}
The progress of science in the field of medicine is currently very rapid along with technological advances, but the use of traditional medicines is increasingly popular. This is due to the low side effects caused by traditional medicines, practical use, easy to obtain and affordable prices. North Sulawesi is one area that has so many types of plants, including leilem plants (Clerodendrum minahassae) of the genus Clerodendrum. Leilem plant is an endemic plant in North Sulawesi which is often consumed by vegetables as a vegetable and is usually added to meat processing. This study aims to determine the effect of ethanol extracts of leilem leaves on the description of urea, uric acid and creatinine values in etylen glycol induced white rats. The study design, the treatment group was divided into 5 groups. The control group (P0), the ethylene glycol group (P1), the rockgin treatment group (P2), the ethanol extract group of leilem leaves at a dose of $150 \mathrm{mg} / \mathrm{kgBB}(\mathrm{P} 3)$, and the ethanol extract group of leilem leaves at a dose of $300 \mathrm{mg} / \mathrm{kgBB}(\mathrm{P} 4)$. The results showed that the ethanol extract of leilem
\end{abstract}


leaves $150 \mathrm{mg} / \mathrm{kgBB}$ and $300 \mathrm{mg} / \mathrm{kgBB}$ could reduce the levels of ureum, creatinine and uric acid in rats with ethylene glycol treatment. Ethanol extract of leilem leaves $150 \mathrm{mg} / \mathrm{kgBB}$ was better in reducing levels of urea, creatinine and uric acid in rats compared with a dose of $300 \mathrm{mg} / \mathrm{kgBB}(\mathrm{p}<0.05)$

Keywords: Leilem, urea, creatinine, uric acid

\section{PENDAHULUAN}

Indonesia merupakan negara yang kaya akan keanekaragaman hayati dengan jenis tumbuhan yang bervariasi dan memiliki peranan penting dalam perkembangan ilmu pengetahuan dan teknologi. Keanekaragaman hayati ini termasuk dalam sumber daya alam yang menghasilkan senyawa kimia yang tidak terbatas jenis dan jumlahnya. Indonesia memiliki jenis tanaman obat yang banyak ragamnya. Jenis tanaman yang termasuk dalam kelompok tanaman obat mencapai lebih dari 1000 jenis. Organisasi Kesehatan Dunia (WHO) melaporkan bahwa secara global $80 \%$ dari semua Negara tergantung pada tanaman obat dan lebih dari 13.000 tanaman telah dilakukan penelitian untuk berbegai penyakit (Choubey, A. $d k k$. 2010). Meskipun Indonesia memiliki keanekaragaman tanaman obat yang melimpah namun sebagian besar belum dimanfaatkan secara optimal. Beberapa tanaman obat selayaknya disebut herba nasional karena telah terbukti selama beberapa tahun meskipun hanya secara empiris (Wiryowidagdo, S. 2009). Paling tidak telah teruji khasiatnya, efektivitas dan keamanannya. Sebagai tanaman asli Indonesia, tanaman obat sudah ada sejak nenek moyang kita dan digunakan untuk memelihara kesehatan, mengobati penyakit dan pengetahuan ini diwariskan secara turun temurun dari generasi ke generasi.

Ginjal termasuk organ tubuh yang sangat vital. Pada umumnya fungsi ginjal adalah mengekskresikan zat sisa seperti urea, asam urat, kreatinin, dan zat lain yang bersifat racun, mengatur volume plasma darah,dan jumlah air di dalam tubuh, menjaga tekanan osmosis dengan cara mengatur ekskresi garam- garam, yaitu membuang jumlah garam yang berlebihan dan menahan garam bila jumlahnya dalam tubuh berkurang, mengatur $\mathrm{pH}$ plasma dan cairan tubuh dengan mengekskresikan urin yang bersifat basa, tetapi dapat pula mengekskresikan urin yang bersifat asam, dan menjalankan fungsi sebagai hormon dengan mengasilkan dua macam zat, yaitu rennin dan eritropoietin yang diduga mempunyai fungsi endokrin. Fungsi ginjal dapat menurun jika faktorfaktor prerenal seperti aliran darah ke ginjal, obstruksi, shock atau hipovolemia berat. Fungsi ginjal juga dapat terganggu akibat faktor postrenal, seperti obstruksi aliran urin pada saluran kemih bawah (Girindra. 1986). Konsentrasi urea, blood urea nitrogen (BUN), kreatinin, amonia, ginjal sangat berkaitan dengan makanan dan minuman yang dikonsumsi. Namun, yang menjadi indikator untuk mendeteksi kerusakan ginjal adalah blood urea nitrogen dan kreatinin, karena akan meningkat dalam darah. Oleh karena itu pemeriksaan blood urea nitrogen dan kreatinin dapat digunakan sebagai indikator untuk mengetahui terjadinya gangguan pada ginjal. Pada gangguan ginjal yang parah kadar blood urea nitrogen dan kreatinin akan meningkat (Japaries, W. 1992).

Sulawesi Utara merupakan salah satu daerah yang memiliki begitu banyak jenis tumbuhan, diantaranya tumbuhan leilem (Clerodendrum minahassae) dari genus Clerodendrum. Tumbuhan leilem merupakan tumbuhan endemik Sulawesi Utara yang oleh masyarakat Minahasa sering dikonsumsi sebagai sayur dan biasanya ditambahkan pada pengolahan daging. Secara empiris masyarakat Minahasa memanfaatkan daun leilem sebagai obat tradisional. Adapun penelitian-penelitian sebelumnya dilaporkan bahwa genus 
Clerodendrum berpotensi sebagai antidiabetes, antihipertensi, antiinflamasi, antioksidan, antimalarial, antitumor, antidiare, antimikroba dan anti hyperlipidemia (Gandhi, A dan J, Srivastava. 2007). Selain itu juga genus Clerodendrum memiliki aktivitas diuretik.

Sampai saat ini pengujian secara ilmiah mengenai pemanfaatan tumbuhan leilem sebagai pengobatan alternatif untuk ginjal belum pernah dilakukan. Oleh karena itu perlu dilakukan penelitian tentang potensi daun leilem dalam mengobati batu ginjal. Untuk urgensi penelitian, penggunaan obat kimia yang masih tinggi namun penggunaan obat herbal itu sendiri masih belum banyak dimanfaatkan, selain itu tingginya penderita penyakit yang berkaitan dengan ginjal.

Penelitian ini bertujuan untuk mengetahui efek pemberian ekstrak etanol daun leilem (Clerodendrum minahasae) terhadap kadar kreatinin, ureum dan asam urat pada tikus putih (Rattus novergicus).

\section{METODE}

\section{Waktu dan Tempat Penelitian}

Penelitian ini dilakukan selama 3 bulan. Perlakuan dan analisis dilakukan di Laboratorium Farmasi Sekolah Tinggi Ilmu Kesehatan Trinita Manado

\section{Alat dan Bahan}

Hewan model: Penelitian ini menggunakan hewan model tikus putih (Rattus norvegicus) dengan bobot kira-kira 150-200 g, sebanyak 20 ekor. Pemberian pakan dan air minum dilakukan secara ad libitum. Tikus-tikus dipelihara di dalam kandang plastik berukuran $25 \mathrm{X}$ $40 \mathrm{~cm}$ dengan penutup kawat secara individual. Sebelum perlakuan dilakukan, tikus-tikus diadaptasikan selama 7 hari.

Tanaman obat: Tanaman obat yang digunakan adalah daun Leilem

\section{Rancangan Penelitian}

Kelompok I : Kelompok Kontrol (P0) (14 hari)

Kelompok II : Kelompok perlakuan (inducer lithiasis) dengan etilen glikol (P1) (14 hari)

Kelompok III : Kelompok perlakuan dengan etilen glikol + Batugin (P2)

Kelompok IV : Kelompok perlakuan dengan etilen glikol (14 hari) + ekstrak etanol daun leilem $150 \mathrm{mg} / \mathrm{kg} \mathrm{BB}$ (14 hari) (P2)

Kelompok V : Kelompok perlakuan dengan etilen glikol (14 hari) + ekstrak etanol daun leilem $300 \mathrm{mg} / \mathrm{kg} \mathrm{BB}$ (14 hari) (P3)

\section{Prosedur Penelitian}

Pembuatan simplisia: Sampel daun leilem yang diperoleh dikeringkan dengan cara dianginanginkan kemudian diblender menjadi serbuk dan disimpan dalam wadah bersih dan tertutup rapat

Pembuatan ekstrak etanol: Ekstraksi daun leilem dilakukan dengan menambahkan etanol ke dalam serbuk daun leilem dengan perbandingan jumlah pelarut dengan serbuk 1: 5. Hasil dari maserasi berupa ekstrak etanol daun leilem kemudian dilakukan evaporasi dengan alat rotary evaporator, untuk menguapkan pelarut sehingga diperoleh ekstrak kental dari daun leilem. 


\section{Uji Aktivitas perusakan ginjal}

Setelah adaptasi, tikus perlakuan untuk kontrol (P0) hanya diberi pakan dan air minum, sedangkan tikus perlakuan P1 diberi induksi etilen glikol $0.75 \%$ selama 14 hari. Kelompok perlakuan P2 diberi induseretilen glikol $0.75 \% 14$ hari kemudian diikuti pemberian batugin. Kelompok perlakuan P3 diberi induseretilen glikol $0.75 \% 14$ hari kemudian diikuti pemberian ekstrak etanol daun leilem $150 \mathrm{mg} / \mathrm{kg}$ BB selama 14 hari.Kelompok perlakuan P4 diberi etilen glikol $0.75 \%$ selama 14 hari kemudian diikuti pemberian ekstrak etanol daun leilem $300 \mathrm{mg} / \mathrm{kgBB}$ selama 14 hari.

\section{Uji ureum, kreatinin dan asam urat.}

Pada akhir percobaan, sebanyak 5 cc darah diambil melalui jantung dengan menggunakan siring. Darah disentrifus dengan kecepatan $10000 \mathrm{rpm}$ selama 10 menit (Ependorf 543R) untuk mendapatkan serum darah guna analisis kadar ureum, kreatinin dan asam urat. Pengujian ureum, kreatinin dan asam urat dilakukan dengan menggunakan Kit Randox ${ }^{\circledR}$ dan dibaca dengan alat Spectrofotometer Hitachi UV/Vis ${ }^{\circledR}$ mouse instrument.

\section{Analisis data}

Analisis kadar kreatinin, ureum dan asam uratmenggunakan perangkat SPSS IBM 20untuk melihat pengaruh perlakuan dari ekstrak eatnol daun leilem.

\section{HASIL DAN PEMBAHASAN}

\section{Ekstraksi}

Sampel daun leilem yang diperoleh dikeringkan dengan cara diangin-anginkan kemudian diblender menjadi serbuk dan disimpan dalam wadah bersih dan tertutup rapat. Ekstraksi daun leilem dilakukan dengan menambahkan etanol ke dalam serbuk daun leilem sebanyak 250 gr dengan perbandingan jumlah pelarut dengan serbuk 1: 5. Maserasi berupa ekstrak etanol daun leilem kemudian dilakukan evaporasi dengan alat rotary evaporator dengan suhu $50^{\circ} \mathrm{C}$ dengan Vakum 175 mbar, hasil dari ekstraksi diperoleh 11 gr ekstrak yang berwarna hijau kecokelatan.dengan aroma khas daun leilem.

Etanol adalah pelarut yang memiliki dua gugus yang berbeda kepolarannya yaitu gugus hidroksil yang bersifat polar dan gugus alkil yang bersifat nonpolar adanya gugusgugus ini sehingga senyawa-senyawa dengan tingkat kepolaran yang berbeda akan terekstrak dalam etanol. Ekstraksi simplisia tumbuhan untuk tujuan obat herbal terbaik digunakan pelarut etanol (Faraouq. 2003). Etanol dapat bercampur dengan air dalam berbagai perbandingan dan mudah dalam penguapan residu yang ada dalam ekstrak. Pelarut metanol, etilasetat atau heksana tidak diperbolehkan karena residu toksik yang dihasilkan

\section{Analisis Kadar ureum, kreatinin dan asam urat dalam serum darah}

Data hasil analisis kadar ureum, kreatinin, dan asam urat yang terdapat pada serum darah tikus disajikan dalam Tabel 1. Hasil analisis menunjukkan dalam taraf $\mathrm{p}<0.05$ kelompok P1 (kelompok etilen glikol) terjadi peningkatan yang signifikan akan kadar ureum, kreatinin dan asam urat dibandingkan dengan kelompok P0 (Normal), Hasil analisis menunjukkan dalam taraf $\mathrm{p}<0.05$ kelompok P2 (kelompok batugin) terjadi penurunan yang signifikan akan kadar ureum, kreatinin dan asam urat dibandingkan dengan kelompok P1 
(kelompok etilen glikol). Hasil analisis menunjukkan dalam taraf $\mathrm{p}<0.05$ kelompok P3 (kelompok perlakuan ekstrak etanol daun leilem $150 \mathrm{mg} / \mathrm{kgBB}$ ) terjadi penurunan akan kadar ureum, kreatinin dan asam urat dibandingkan dengan kelompok P4 (kelompok perlakuan ekstrak etanol daun leilem $300 \mathrm{mg} / \mathrm{kgBB}$ ).

Tabel 1. Kadar ureum, kreatinin, dan asam urat di dalam serum darah tikus jantan pada masing-masing kelompok

\begin{tabular}{|c|c|c|c|}
\hline PERLAKUAN & $\begin{array}{c}\text { UREUM } \\
(\mathrm{mg} / \mathrm{dL})\end{array}$ & $\begin{array}{c}\text { KREATININ } \\
(\mathrm{mg} / \mathrm{dL})\end{array}$ & $\begin{array}{c}\text { ASAM URAT } \\
(\mathrm{mg} / \mathrm{dL})\end{array}$ \\
\hline Normal (P0) & $28.50 \pm 1.12$ & $0.63 \pm 0.08$ & $2.20 \pm 0.23$ \\
\hline Etilen Glikol (P1) & $53.02 \pm 0.91$ & $0.93 \pm 0.03$ & $4.38 \pm 0.39$ \\
\hline Batugin (P2) & $38.10 \pm 0.71$ & $0.60 \pm 0.18$ & $2.10 \pm 0.07$ \\
\hline $\begin{array}{c}\text { Ekstrak Leilem 150 } \\
\text { mg/KgBB (P3) }\end{array}$ & $48.60 \pm 1.09$ & $0.56 \pm 0.07$ & $1.84 \pm 0.37$ \\
\hline $\begin{array}{c}\text { Ekstrak Leilem 300 } \\
\mathrm{mg} / \mathrm{KgBB}(\mathrm{P} 4)\end{array}$ & $62.76 \pm 0.60$ & $0.74 \pm 0.02$ & $1.93 \pm 0.03$ \\
\hline
\end{tabular}

Disajikan dalam rataan dan SD $\mathrm{P}<0.05$

Hasil analisis kadar ureum, kreatinin dan asam urat pada tabel 1 menunjukkan bahwa rataan nilai Ureum sebelum perlakuan (P0) adalah $28.50 \mathrm{mg} / \mathrm{dL}$, setelah diberikan perlakuan etilen glikol $0.75 \%$ kadar ureum mengalami peningkatan menjadi $53.02 \mathrm{mg} / \mathrm{dL}$, kemudian pada saat diberikan perlakuan batugin kadar ureum mengalami penurunan menjadi 38.10 $\mathrm{mg} / \mathrm{dL}$ dan pada saat diberikan ekstrak daun leilem $150 \mathrm{mg} / \mathrm{kg}$ BB kadar ureum terus mengalami penurunan menjadi $48.60 \mathrm{mg} / \mathrm{dL}$, dan saat diberikan ekstrak daun leilem 300 $\mathrm{mg} / \mathrm{kg}$ BB kadar ureum mengalami peningkatam menjadi $62.76 \mathrm{mg} / \mathrm{dL}$. Kadar ureum normal pada tikus putih adalah 15.0 - $21.0 \mathrm{mg} / \mathrm{dL}$ (Malole dan Pramono, 1989).

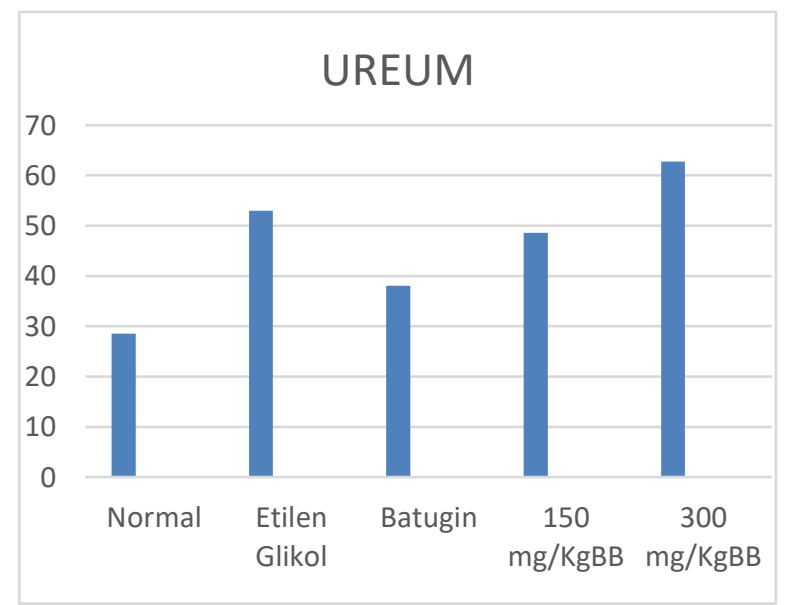

\section{Gambar 1. Hasil analisis kadar ureum}

Kadar ureum yang tinggi pada semua kelompok perlakuan mungkin diakibatkan oleh pemberian pakan yang mengandung protein tinggi. Makanan dengan protein yang tinggi akan meningkatkan pelepasan asam amino ke dalam darah, yang kemudian direabsorbsi di tubulus 
proksimal, karena asam amino dan natrium direabsorbsi bersama oleh tubulus proksimal, maka kenaikan reabsorbsi asam amino juga merangsang reabsorbsi natrium dalam tubulus proksimal (Guyton dan Hall, 1997). Penurunan pengiriman natrium ke makula densa ini kemudian menimbulkan penurunan tahanan arteriol aferen yang diperantarai oleh umpan balik tubuloglomerulus sehingga meningkatkan aliran darah ginjal dan gromerular filtration rate (GFR). Kenaikan GFR ini menyebabkan ekskresi natrium dipertahankan pada kadar yang mendekati normal sementara terjadi kenaikan ekskresi produk sisa dari metabolisme protein, seperti ureum. Peningkatan kadar ureum dalam darah tidak hanya disebabkan oleh penurunan proses filtrasi glomerulus akibat gangguan fungsi ginjal. Keadaan dehidrasi cairan tubuh akan meningkatkan kadar ureum dalam darah karena proses reabsorbsi urea pada ginjal juga meningkat.

Dari hasil analisis kreatinin yang dilakukan dapat dilihat bahwa rataan nilai Kreatinin sebelum perlakuan (P0) adalah $0.63 \mathrm{mg} / \mathrm{dL}$, setelah diberikan perlakuan etilen glikol $0.75 \%$ kadar kreatinin mengalami peningkatan menjadi $0.93 \mathrm{mg} / \mathrm{dL}$, kemudian pada saat diberikan perlakuan Batugin kadar kreatinin mengalami penurunan menjadi $0.60 \mathrm{mg} / \mathrm{dL}$ dan pada saat diberikan ekstrak daun leilem $150 \mathrm{mg} / \mathrm{kgBB}$ kadar kreatinin terus mengalami penurunan menjadi $0.56 \mathrm{mg} / \mathrm{dL}$, dan ekstrak daun leilem $300 \mathrm{mg} / \mathrm{kgBB}$ kadar kreatinin mengalami peningkatan menjadi $0.74 \mathrm{mg} / \mathrm{dL}$.

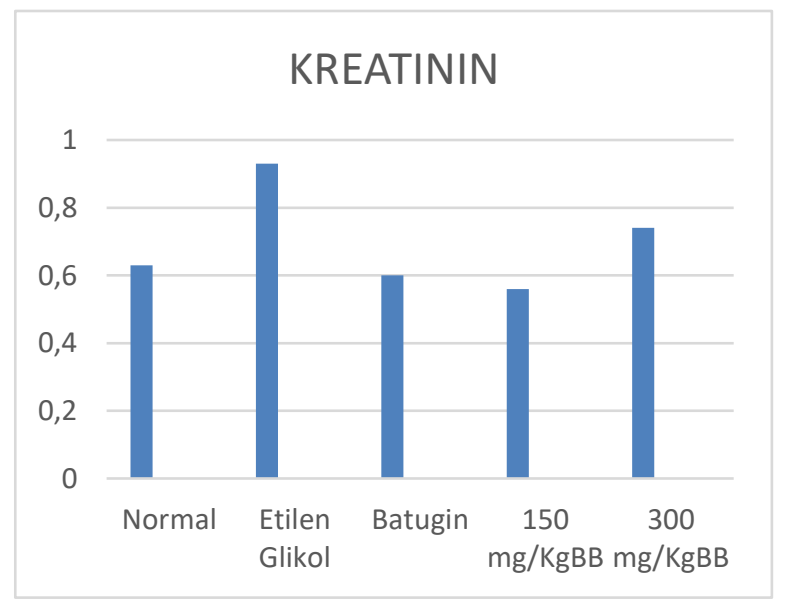

Gambar 2. Hasil analisis kreatinin

Malole dan Pramono (1989) menyatakan bahwa kadar normal kreatinin plasma darah pada tikus adalah 0.2 - $0.8 \mathrm{mg} / \mathrm{dl}$. Kenaikan kadar kreatinin dalam plasma selalu mengindikasikan adanya penurunan ekskresi yang disebabkan oleh adanya gangguan fungsi ginjal. Kreatinin merupakan bentuk anhidrida dari kreatin yang sebagian besar disintesis di dalam otot melalui proses dehidrasi non-enzimatik dari keratin fosfat. Keratinin juga terdapat pada otak dan darah dalam bentuk fosfokreatin maupun bebas. Kreatinin diekskresikan seluruhnya kedalam urin melalui filtrasi glomerulus. Meningkatnya kadar kreatinin dalam darah merupakan indikasi rusaknya ginjal,

Dari hasil analisis asam urat yang dilakukan dapat dilihat bahwa rataan nilai asam urat sebelum perlakuan (P0) adalah $2.20 \mathrm{mg} / \mathrm{dL}$, setelah diberikan perlakuan etilen glikol $0.75 \%$ kadar asam urat mengalami peningkatan menjadi $4.38 \mathrm{mg} / \mathrm{dL}$, kemudian pada saat diberikan perlakuan batugin kadar asam urat mengalami penurunan menjadi $2.10 \mathrm{mg} / \mathrm{dL}$ dan 
pada saat diberikan ekstrak daun leilem $150 \mathrm{mg} / \mathrm{kgBB}$ kadar asam urat terus mengalami penurunan menjadi $1.84 \mathrm{mg} / \mathrm{dL}$, kemudian pada saat diberikan ekstrak daun leilem 300 $\mathrm{mg} / \mathrm{kgBB}$ kadar asam urat terus mengalami peningkatan menjadi $1.93 \mathrm{mg} / \mathrm{dL}$ Kadar normal asam urat darah pada tikus adalah 1.2-5.0 mg/dL (Mudrikah, F.2006).

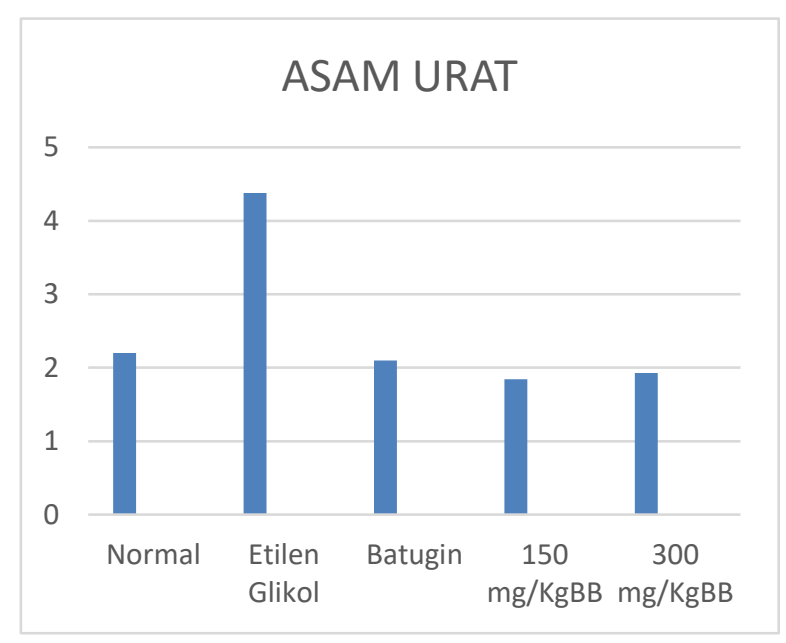

Gambar 3. Hasil analisis asam urat

Induksi etilen glikol menyebabkan berkurangnya kinerja ginjal yang ditandai dengan tinggi kadar kreatinin dan ureum dalam serum darah serta kurang efisiennya filtrasi glomerulus. Hal ini menyebabkan meningkatnya kadar asam urat dalam darah (Syukri, 2007). Asam urat akan dibawa ke ginjal melalui aliran darah untuk dikeluarkan bersama air seni. Ginjal akan mengatur kadar asam urat dalam darah agar selalu dalam keadaan normal. Namun, asam urat yang berlebihan tidak akan tertampung dan termetabolisme seluruhnya oleh tubuh, maka akan terjadi peningkatan kadar asam urat dalam darah.

Dalam penelitian ini tikus yang digunakan adalah tikus putih jantan hal ini dikarenakan penggunaan tikus jantan sebagai hewan coba untuk urolitiasis memiliki sistem urinaria yang menyerupai sistem urinaria pada manusia (Vermeulen, C.V. 1962). Prosentase terjadinya urolitiasis pada tikus jantan mencapai $70-81 \%$ dan pada tikus betina $47-60 \%$. Ini disebabkan karena tikus jantan memiliki hormon testosteron yang dapat meningkatkan terjadinya batu ginjal, sedangkan pada tikus betina karena adanya hormon estrogen ternyata menghambat pembentukkan batu ginjal (Devi, V.K, $d k k ., 1993$; Lee, Y, C.H, $d k k,$. 1996; Joy, J.W, dkk., 2012).

Pemberian etilen glikol dalam penelitian ini adalah untuk merangsang terbentuknya urolitiasis, karena etilen glikol merupakan agen nefrotoksik yang sering digunakan pada suatu eksperimen dengan hewan model tikus untuk merangsang terbentuknya kalsium oksalat di ginjal. Etilen glikol diserap dan dimetabolisme di hati oleh enzim alkohol dehydrogenase atau aldehid dehydrogenase menjadi asam glikolat. Asam glikolat kemudian dioksidasi menjadi asam glioksalat yang selanjutnya dioksidasi menjadi asam oksalat oleh enzim glikolat oksidase atau laktat dehydrogenase. Asam oksalat merupakan pemicu terjadinya hiperoksalouria. Senyawa metabolik oksalat dapat berikatan dengan kalsium dalam darah membentuk kristal kalsium oksalat dan mengendap di ginjal (Palmar, R.K. $d k k$. 
2012). Pemberian etilen glikol dapat menyebabkan tubular nekrosis akut sehingga kadar ureum dalam plasma darah menjadi lebih tinggi. Pembentukkan batu ginjal pada tikus yang diberi etilen glikol disebabkan oleh hiperoksaloria yang pada akhirnya menyebabkan peningkatan retensi dan ekskresi oksalat (Umesh dan Christinia, 2011) Peningkatan oksalat dilaporkan merangsang peroksisasi lipid dan menyebabkan kerusakan jaringan oleh karena bereaksi dengan asam lemak polyunsaturated pada membran sel (Ernster L., K, 1967).

Pemberian ekstrak etanol daun Leilem dosis $150 \mathrm{mg} / \mathrm{kgBB}$ pada tikus yang diberikan etilen glikol sebelumnya ternyata menunjukkan penurunan kadar Ureum, Kreatinin dan Asam urat yang lebih baik dari pada pemberian ekstrak leilem dosis $300 \mathrm{mg} / \mathrm{kgBB}$. Untuk dosis ekstrak leilem $150 \mathrm{mg} / \mathrm{kgBB}$ terlihat memiliki kemampuan lebih baik dalam menurunkan kadar kreatinin, ureum dan asam urat yang sama dengan batugin.

Penelitian menujukan bahwa genus Clerodendrum mengandung senyawa kimia aktif seperti flavonoid, fenol, terpenoid dan steroid (Shrivastava, N., Patel, T. 2007). Flavonoid merupakan senyawa metabolit sekunder yang terdapat pada tanaman hijau, kecuali alga. Flavonoid termasuk senyawa fenolik alam yang potensial sebagai antioksidan dan mempunyai bioaktifitas sebagai obat. Senyawa flavonoid terdapat dalam semua bagian tumbuhan tinggi, seperti bunga, daun, ranting, buah, kayu, kulit kayu dan akar. Akan tetapi senyawa flavonoid tertentu sering terkonsentrasi dalam suatu jaringan tertentu, seperti daun, bunga dan buah. Sebagian beasar flavonoid alam ditemukan dalam bentuk glukosa. Falvonoid dalam tubuh manusia berfungsi sebagai antioksidan sehingga sangat baik untuk pencegahan kanker. Manfaat flavonoid antara lain untuk melindungi struktur sel, meningkatkan efektivitas vitamin $\mathrm{C}$, anti inflamasi, mencegah keropos tulang dan sebagai antibiotik.

Efek flavonoid sebagai antioksidan secara tidak langsung juga mendukung efek antiinflamasi flavonoid. Adanya radikal bebas dapat menarik berbagai mediator inflamasi (Nijveldt, R. J., E, $d k k ., 2001$ ). Senyawa flavonoid yang dapat berfungsi sebagai anti inflamasi adalah toksifolin, biazilin, haematoksilin, gosipin, prosianidin, dan nepritin. Hasil penelitian menyatakan bahwa pemberian flavonoid dapat meningkatkan glomerular filtration rate (GFR). Peningkatan glomerular filtration rate pada ginjal akan mengakibatkan ekskresi terhadap ureum dan kreatinin juga meningkat sehingga kadar ureum dan kreatinin dalam darah menurun (Jouad, $d k k ., 2001$ ). Penurunan kadar asam urat dalam serum darah setelah perlakuan dengan ekstrak tanaman menunjukkan penghambatan aktivitas xantin oksidase (Susendi.2011). Hal ini sejalan dengan pendapat Mudrikah yang menunjukkan bahwa beberapa golongan alkaloid dan flavonoid dapat bekerja sebagai inhibitor xantin oksidase (Mudrikah, F.2006).

Pemanfaatan tanaman obat sangat manjur karena memiliki efek samping yang rendah dibandingkan dengan obat-obat modern. Selain itu, dapat mengurangi laju terulangnya penyakit batu ginjal (Prasad' $d k k$., 2007). Tanaman obat juga mengatur metabolisme oksalat dengan menjaga keseimbangan antara inhibitor dan promotor pembentuk kristal dan mempunyai aktifitas antioksidan, anti mikroba, analgesik serta antiinflamasi (Kore, $d k k ., 2011)$, memperbaiki fungsi ginjal, mengatur metabolisme oksalat, mengatur keseimbangan koloid kristaloid dan cara memperbaiki fungsi ginjal sehingga mencegah terulangnya kembali batu ginjal, aktivitas antioksidan dengan memperbaiki jaringan renalis dan keutuhan sel, aktivitas antimikroba oleh karena memiliki aktivitas anti infeksi dengan melawan organisme penyebabnya (Pareta, $d k k ., 2012)$ 


\section{KESIMPULAN}

Ekstrak daun leilem memiliki aktivitas dalam menurunkan kadar kreatinin, ureum dan asam urat. Dosis ekstrak daun leilem paling efektif dalam menurunkan kadar kreatinin, ureum dan asam urat adalah dosis ekstrak $150 \mathrm{mg} / \mathrm{kgBB}$.

\section{DAFTAR RUJUKAN}

Choubey, A. $d k k$. 2010. Potensial medical plants in kidney, gall and urinary stoe. Int J of Drug Development and Research, Vol.2.9344.

Devi, V.K., R. Baskar, P. Varalakshmi. 1993. Biochemical effect in normal and stone forming rats treated with the ripe kernel juice of Plantain (Musa Paradisiaca). Ancient Scie.of Life. 4:451-461.

Ernster L., K. Nordenbrand.Oxidation and phosphorylation.In, Methods in Enzymology, edited by Ronad. W. E., Maynard. E. P, vol-10 (Academic Press, New York) 1967, 574-580.

Faraouq. 2003. Esktrak sebagai salah satu pengembangan bentuk obat tradisional. Prosiding Seminar Nasional Tumbuhan Obat Indonesia XXIII. Jakarta.

Girindra. 1986. Biokimia I. Jakarta: PT. Gramedia

Guyton AC, Hall JE. 1997. Buku Ajar Fisiologi Kedokteran. Ed ke-9. Jakarta: Penerbit Buku Kedokteran EGC.

Japaries, W. 1992. Penyakit Ginjal. Penerbit Arcan. Jakarta.

Jouad, H., M.A. Lacaille-Dubois, B. Lyoussi, M. Eddouks. 2001. Effects of The Flavonoids Extracted from Spergularia purpurea Pers. on Arterial Blood Pressure and Renal Function in Normal and Hypertensive Rats. Journal of Ethnopharmacology. 72 (2): 159-163.

Joy, J.W., S. Prathyusha., S. Mohanalakshmi., A.V.S. Praveen Kumar., C.K. Ashok Kumar. 2012. Potent Herbal Wealth with Litholytic Activity. A Review.Int. J. Innovative Drug Discovery. 2:66-75

Kore, K.J. R.V. Shete, P.J/ Jadhav, M.P. Kabra. 2011. Antiurolithiatic effect of hidroalkoholic extract of lawsonia inermis L. leaves. Int Jof Universal pharmacy and life sciences.

Lee, Y, C.H. Wan, K.H Yong and S.C. Luke. 1996. Testosterone enhances whereas estrogen inhibits calcium oxalate stone formation in ethylene glycol treated Rats. The J. of Urology.156:502-505.

Malole, M.B.M, C.S.U. Pramono .1989. Pengantar Hewan-hewan Percobaan di Laboratorium. Bogor: Pusat Antara Universitas Bioteknologi IPB.

Mudrikah, F.2006. Potensi ekstrak jahe merah (Zingiberofficinale Rosc) dan campurannya dengan herba suruhan (Peperomiapellucida L) sebagai antihiperurisemia pada tikus.Skripsi. IPB. 
Nijveldt, R. J., E. van Nood, D.E.C. van Hoorn, P.G. Boelens, K. van Norren, P.A.M. van Leeuwen. 2001. Flavonoids: a review of probable mechanisms of action and potential applications. American Journal of Clinical and Nutrition 74: 418-425.

P, Gandhi, A dan J, Srivastava. 2007. Studies on the Production of Protein Isolates from Defatted Sesame Seed (Sesame indicum) Flour and Their Nutritional Profile. ASEAN Food Journal. 14 (3): 175-180).

Palmar, R.K. dkk. 2012. Preclinical evaluation of Antiurolithiatic Activity of Swertia chirata steam. Int. Res. J Pharmacy 3:198-202.

Pareta, S. K., K. C. Patra, P. M. Mazumder, D. Sasmal. 2012. Establishing the Principle of Herbal Terapy for Antiurolithiatic Activity: A Review. Journal of Parmacology and Toxicology 6 (3):321-332.

Prasad, K. V. R. S. G., D. Sujatha and K. Barti. 2007. Herbal drugs in urolithiasis: A review. Pharmacog. Rev., 1:175-179.

Shrivastava, N., Patel, T. 2007. Clerodendrum and Heathcare an overview, Medicinal and Aromatic Palnt Science and Biotechnology. Gujarat. India.

Susendi.2011. Aktivitas Antihiperurisemia ekstrak air jinten hitam (Coleusambonicus Lour) pada mencit jantan galur balb-c dan standardisasinya. Majalah Farmasi Indonesia, 22(2), $77-84$.

Syukri, 2007.Asam Urat dan Hiperuresemia. Majalah Kedokteran Nusantara Volume 40 No. 1 Maret 2007.

Umesh, G., A. J. M. Christina. 2011. Effect of Ratula aquatica L on ethylene-glycol induced urolithiasis in rats.

Vermeulen, C.V. 1962. Experiments on causation of urinary calculi, in Essay in Experimental Biology. University of Chicago Press (Chicago) 253-269.

Wiryowidagdo, S. 2009. Obat Ginjal dari kumis kucing hingga sambiloto.http://kesehatankompas.com (11 November 2019). 